\title{
Functional Evaluation Framework for Nigerian University Websites
}

\author{
Abubakar Aliyu Machina \\ Research Scholar, School of Computer Science \& \\ Information Technology, Changchun University of \\ Science and Technology \\ Changchun, Jilin Province, China
}

\author{
Li Songjiang \\ Dr, Senior Lecturer, School of Computer Science \\ \& Information Technology, \\ Changchun University of Science and Technology \\ Changchun, Jilin Province, China
}

\begin{abstract}
Institutions of learning adopt the use of Websites to portray their activities and provide an easy avenue of communication between all stakeholders (i.e. students, parents, academic \& non-academic staff, and the general public). However, most academic institutions set to undermine/underutilize the power of this important tool. Therefore, a multi-facet approach is adopted to review related literature, analyzed and benchmark world top ranking university websites, exploring their unique features and functionalities. This study proposed a standard functional evaluation framework considered to be valid, reliable and efficient in evaluating the quality of university websites across distinct dimensions and put to test the framework by evaluating the first- and second-generation universities in Nigeria. The evaluation results suggested some of the characteristics that are lacking or need improvements.
\end{abstract}

\section{Keywords}

Website Evaluation, framework, Functional, University/Academic Websites, Usability Engineering.

\section{INTRODUCTION}

Information and Communication Technology (ICT) serves as a multipurpose and inter- disciplinary tool used to proposed solution to a wide range of problems. Considering the current trend in ICT, it is generally accepted in the academia at various capacities. The most common utilization of ICT in Nigerian tertiary institutions is the use of 'website' as the first point of contact. Website gives first impression about an institution through portraying its activities, achievements, resources, research interest and served as a medium for communication between institution and the otherworld. Similarly, students can have access to course materials, register courses, check bus schedules, timetable, result, and other valuable information. Despite the advantage, some institutions are yet to explore and put to good use the full potential of their websites. Some University websites are of low quality, difficult to access, have poor content and poor upload and download time [1].

Recently, there have been a booming interest among usability engineers and computer scientists on evaluating and proposing a framework or standard for evaluating University websites. Andalib \& Danaee [2] conducted a study on measuring the quality of a university website. Arnold \& Andrew investigate Users Satisfaction and Experience on Academic Websites: A Case of Selected Nigerian Universities Websites [3], Design Evaluation of some Nigerian University website: a programmers point of view [4], Contents and Architecture of Nigerian Universities' Websites [5], Usability Evaluation of Some Selected Nigerian Universities' Websites quality: a comparative analysis [1]. However, based on the available reviewed literature it is apparent that different researchers adopt distinctive approach in evaluating the quality of University websites, most of which focused on the usability and the programming concept while given less attention to the essential functionalities that are lacking in the websites. In contrast the use of literature review, sample evaluation, and proposed framework testing is used to conduct this research.

Hence, the objective of this research is to develop a practical, function-based, and measurable framework for evaluating the quality of Nigerian University websites to provide a clear criterion to encourage improvements of website design and its implementation especially in the Nigerian context. Moreover, the findings of this research paper can serve as a reference points for University website content managers and or administrators. This paper is outlined as follows; Literature Review, Research Methodology, Proposed Framework, Data analysis and results

\section{LITERATURE REVIEW}

The most widely used websites are academic websites [6], [7] it serves a wide range of purposes such as academic research, e-learning supports, medium for communication, program promotion, advertising vacancies, academic offerings and opportunities etc. A good website should be user-friendly and represent a functional, accessible, flexible, simple and organized layout, structure and up-to-date content [8] with good information quality. It should enable fast, simple and effective interaction irrespective of users experience, knowledge or profile [9]. There exists number of related works and or attempts to evaluate the quality of university websites. As the reliance on websites and web services increases the need to evaluate website quality, strength and weaknesses is proportionally increasing [10]. However, website quality is an intangible concept that is difficult to measure in an operational way [9],[11] hence, its absence is easily noticed [6]. Website quality could be measured in two perspective: programmers and end-users, programmers focus on functionality, security, maintainability etc. Whilst endusers are centered to usability, efficiency, creditability, consistency etc. [12].

Therefore, researchers have an un-tallying perception and means of assessing university websites. [13] proposed a quality-based framework for evaluating academic websites. [14] proposed five evaluation procedure based on usability principles; some of which include learning from existing sites. Islam \& Tsuji used questionnaire, html toolbox and webpage analyzer to evaluate the usage of university websites in Bangladesh from a usability perspective by measuring internal features of websites [15]. Alahmadi \& Drew carried-out accessibility evaluation of top ranking universities website in Oceania and Arab categories for home, admission and course description page using AChecker, and the studies indicated 
the growing need to improve on accessibility [16]. Jasmin et al, conducted a comparative analysis of Maritime Universities websites [9]. While Layla evaluate the usability of educational websites with reference to design characteristics [17], Qi et al, identify the characteristics of academic website quality of Telkom University based on ISO/IEC 9126 standard [8]. While others used advanced method such as [18] backpropagation neural network and support vector machines using four evaluation indicators; educational content, operability, technical character, and artistry. [19] Use web diagnostic tools to propose a methodology for determining and evaluating the best Malaysian university website using Linear Weightage Model, Analytical Hierarchy Process, Fuzzy Analytical Hierarchy Process, and new hybrid model.

Specifically, many studies attempted evaluation of Nigerian University Websites [1], [3]-[5], [20]-[22] considering various evaluation criteria. Usability evaluation covered by [21] revealed that some of the first and second generation university websites are below acceptable threshold values and [4] deduct that most academic portals are averagely designed while taking less advantage of the functions, citing University of Lagos and Federal University of Minna having the best portal design and University of Abuja with relatively poor design. The outcome of [3] confirmed previous studies evaluating educational websites and highlight specific problems related to lack of navigational support links/tools, ineffective internal search function, inappropriate page design and incomplete data are identified. [5] Adds, most websites lack good architecture and relevant content. Observations showed that Nigerian universities adopt online registration [5]. Hence, as a drawback manual intervention of nonacademic staff and mostly over-the-counter payment method are still in existence.

Based on the reviewed literature, it is evident that further work is required in this domain i.e. on evaluating Nigerian university websites. Hence, websites design ideas are constantly changing, and there is a need for various researches to explore or identify areas that needs improvement; as websites development is a continuous and dynamic task that changes in time. Therefore, it requires long term editorial and technical management [7].

\section{RESEARCH METHODOLOGY}

In conducting this research, a multi-phase approach was adopted; starting from problem identification via review of related literature, research procedure, data collection, and data analysis and discussion. Primarily, the research purpose is in two category 1. Propose a new framework for evaluating the quality of Nigerian University websites. 2. To evaluate selected university websites based on the criteria proposed in the framework. Firstly, Five top University websites according to a webometrics world ranking of University websites updated in 2019 [24] was culled out of 28,000 institutions. These websites were comparatively reviewed and benchmarked while exploring their outstanding features and functionalities.

Table 1 Unique benchmarked Functionalities or Features

\begin{tabular}{|c|c|c|c|c|c|}
\hline 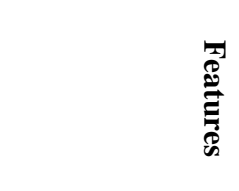 & 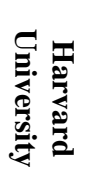 & 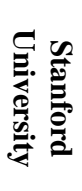 & 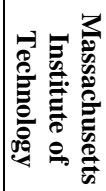 & 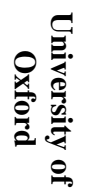 & 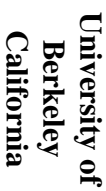 \\
\hline $\begin{array}{c}\mathrm{e}- \\
\text { Library/Catalogue }\end{array}$ & $\bullet$ & $\bullet$ & • & $\bullet$ & • \\
\hline
\end{tabular}

\begin{tabular}{|c|c|c|c|c|c|}
\hline $\begin{array}{c}\text { Parent } \\
\text { Portal/Forum }\end{array}$ & $\bullet$ & $\bullet$ & $\bullet$ & $\bullet$ & $\bullet$ \\
\hline Admissions & $\bullet$ & $\bullet$ & $\bullet$ & $\bullet$ & $\bullet$ \\
\hline Info in Numbers & $\bullet$ & $\bullet$ & $\bullet$ & $\bullet$ & $\bullet$ \\
\hline Search Function & $\bullet$ & $\bullet$ & $\bullet$ & $\bullet$ & $\bullet$ \\
\hline $\begin{array}{c}\text { Course } \\
\text { description }\end{array}$ & $\bullet$ & $\bullet$ & $\bullet$ & $\bullet$ & $\bullet$ \\
\hline Resources & $\bullet$ & $\bullet$ & $\bullet$ & $\bullet$ & $\bullet$ \\
\hline \begin{tabular}{c} 
Compatibility \\
\hline $\begin{array}{c}\text { Social Media } \\
\text { Integration }\end{array}$
\end{tabular} & $\bullet$ & $\bullet$ & $\bullet$ & $\bullet$ & $\bullet$ \\
\hline
\end{tabular}

Secondly, Eighteen federal universities were selected based on year of establishment starting from 1948 to 1985 [23]. Therefore, comprising of the first- and second-generation universities across Nigeria. The websites were evaluated using the proposed functional framework. The process of this evaluation will go through the guideline that each Available and Functional criterion is rated 2, Available but not functional rated 1 and not available rated 0 as summarized in the condition below;

Evaluation $=\left\{\begin{array}{ccc}2, \quad \text { if } \begin{array}{c}\text { Available, } \\ \text { Functional, } \\ \text { Complete, } \\ \text { Consistent. }\end{array} \\ 1, \text { if } \begin{array}{l}\text { Available, } \\ \text { Not Functional, } \\ \text { Incomplete, } \\ \text { Inconsistent. }\end{array} \\ \\ 0 . & \text { Otherwise. }\end{array}\right.$

The results were thoroughly discussed and analyzed using excel and simple pie charts, column charts and bar chats to present the outcome of each criteria.

\section{THE PROPOSED EVALUATION FRAME WORK}

In designing the proposed evaluation framework, important key attributes of academic websites were studied while functionality is given preference. The proposed framework attempts to identify measurable features of a websites. Identifying first, the availability and completeness of the feature. Since, for any framework or evaluation methods to be applied the feature has to be available. Hence, most of the literature that evaluates Nigerian university websites did not consider this factor.

The objective is to identify measurable functions that are indicators of good, useful, and self-explanatory university websites that suit the Nigerian learning institutions. Each of the evaluation criteria is reviewed considering the relevance, importance or role of the features to university, students and general users or public. The table 1 summarizes the criteria description of the proposed framework. 
Table 2 criteria description of the proposed framework

\begin{tabular}{|c|c|c|}
\hline S/No & Criteria & Description \\
\hline 1 & $\begin{array}{c}\text { Online catalogue or } \\
\text { library }\end{array}$ & $\begin{array}{l}\text { Internet a tool for library } \\
\text { services that serve as a } \\
\text { medium for exchange of } \\
\text { information and knowledge } \\
\text { [25]. Therefore, online library } \\
\text { contains various literatures } \\
\text { and knowledge in vast sources } \\
\text { and format. Without } \\
\text { constraint of time or location } \\
\text { information can be accessed } \\
\text { in various formats such as } \\
\text { books, research journals, } \\
\text { magazines, video tutorials etc. } \\
\text { A university library portal } \\
\text { should also contain best } \\
\text { graduation thesis, past } \\
\text { question papers, and research } \\
\text { projects. See Appendix C. }\end{array}$ \\
\hline 2 & $\begin{array}{c}\text { Mobile and portable } \\
\text { device } \\
\text { compatibility }\end{array}$ & $\begin{array}{l}\text { An academic website should } \\
\text { be compatible with portable } \\
\text { devices for easy access by } \\
\text { student whose majority do not } \\
\text { have access to computers. } \\
\text { Compatibility allows ease of } \\
\text { use and unrestricted access to } \\
\text { information. }\end{array}$ \\
\hline 3 & $\begin{array}{c}\text { Research Interest \& } \\
\text { achievement }\end{array}$ & $\begin{array}{l}\text { University Websites as first } \\
\text { point of contact should } \\
\text { highlight the achievements of } \\
\text { institution and its experts' } \\
\text { personnel in a timeline format } \\
\text { see } \frac{\text { Appendix A. Institution }}{\text { research interest or }} \\
\text { specialization should also be } \\
\text { presented. }\end{array}$ \\
\hline 4 & Student portal & $\begin{array}{l}\text { A point of access that allows } \\
\text { student to view and manage } \\
\text { academic and personal } \\
\text { information. A good portal } \\
\text { allows student to register } \\
\text { courses, view results, view } \\
\text { time table or schedules, } \\
\text { submit assignments, update } \\
\text { personal information etc. }\end{array}$ \\
\hline 5 & Resources & $\begin{array}{l}\text { Access to resources should be } \\
\text { granted to all users such as } \\
\text { simple frequently used forms, } \\
\text { timetable, brochure, access to } \\
\text { OER, link to important sites, } \\
\text { and free school licensed or } \\
\text { registered software. }\end{array}$ \\
\hline 6 & $\begin{array}{l}\text { Comprehensive } \\
\text { search function }\end{array}$ & $\begin{array}{l}\text { Search functionality is an } \\
\text { important feature that allow } \\
\text { users to directly look for } \\
\text { information in the websites. A } \\
\text { comprehensive search } \\
\text { function should be able to } \\
\text { filter search keyword or } \\
\text { phrases within full content of } \\
\text { the website. As Users of } \\
\text { academic websites expect } \\
\text { specific type of information }\end{array}$ \\
\hline
\end{tabular}

\begin{tabular}{|c|c|c|}
\hline & & timely [13]. \\
\hline 7 & $\begin{array}{l}\text { Detailed course } \\
\text { description and } \\
\text { requirement }\end{array}$ & $\begin{array}{l}\text { Academic websites should } \\
\text { consist of accurate and } \\
\text { complete contents of courses } \\
\text { and enough guidance } \\
\text { materials [18]. The section } \\
\text { should describe the available } \\
\text { course offered in institutions } \\
\text { detailing the course overview, } \\
\text { structure, modules, } \\
\text { assessment criteria, duration, } \\
\text { admission requirements, } \\
\text { prerequisite knowledge for the } \\
\text { course see Appendix B. }\end{array}$ \\
\hline 8 & Parent portal & $\begin{array}{l}\text { Through the portal parent can } \\
\text { be supportive and informed } \\
\text { about academic and social } \\
\text { status of their wards, and } \\
\text { equally check their } \\
\text { performance. The portal can } \\
\text { also allow parent to access } \\
\text { reliable school information } \\
\text { and programs. E.g. Appendix } \\
\underline{\text { D. }}\end{array}$ \\
\hline 9 & $\begin{array}{l}\text { Social media } \\
\text { integration }\end{array}$ & $\begin{array}{l}\text { Important tool to instantly } \\
\text { reach and communicate with } \\
\text { large number of individuals. }\end{array}$ \\
\hline 10 & $\begin{array}{c}\text { Content, Structuring } \\
\text { \& Layout }\end{array}$ & $\begin{array}{l}\text { This feature answers the } \\
\text { question of how and what } \\
\text { content are used in a website, } \\
\text { considering both usability, } \\
\text { suitability, navigation, multi- } \\
\text { media and web technology } \\
\text { used. Website with good } \\
\text { content structuring \& layout } \\
\text { should be simple, } \\
\text { understandable and easy to } \\
\text { search intended information. } \\
\text { Content include seven } \\
\text { subcategories, namely; up-to- } \\
\text { date information, relevant } \\
\text { information, no uncompleted } \\
\text { pages, accurate information, } \\
\text { information about the } \\
\text { university, information about } \\
\text { the colleges, information } \\
\text { about departments [17]. }\end{array}$ \\
\hline 11 & Info in numbers & $\begin{array}{l}\text { Too much textual information } \\
\text { is difficult to read, thus, make } \\
\text { a website look complicated. } \\
\text { Alternatively, numbers are } \\
\text { used to represent general } \\
\text { information especially in the } \\
\text { home page of a university } \\
\text { website. See Appendix E. }\end{array}$ \\
\hline 12 & Admissions & $\begin{array}{l}\text { This feature includes all } \\
\text { admission related information, } \\
\text { starting from cut-off mark, list } \\
\text { of successful candidates and } \\
\text { other admission requirements } \\
\text { or statistics. The feature } \\
\text { should allow applicants to } \\
\text { check or track admission } \\
\text { information or processes. }\end{array}$ \\
\hline
\end{tabular}




\section{DATA ANALYSIS AND RESULT}

Table 3 Functional Evaluation of 18 Federal Universities (Data collected between January - June, 2019)

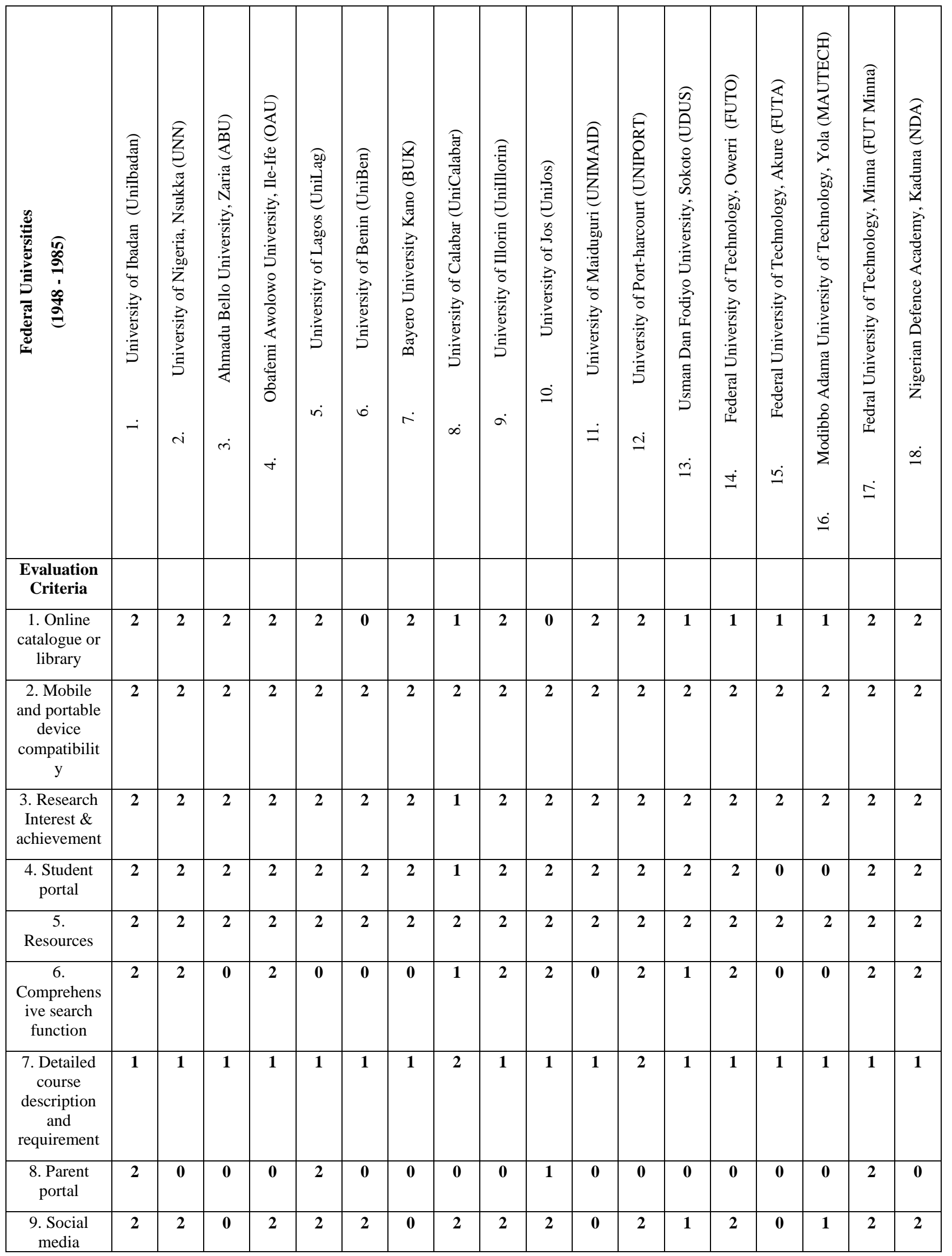




\begin{tabular}{|c|c|c|c|c|c|c|c|c|c|c|c|c|c|c|c|c|c|c|}
\hline integration & & & & & & & & & & & & & & & & & & \\
\hline $\begin{array}{l}\text { 10. Content } \\
\text { Structuring } \\
\text { \& Layout }\end{array}$ & 2 & 2 & 2 & 2 & 2 & 0 & 1 & 2 & 2 & 2 & 2 & 2 & $\mathbf{0}$ & 2 & $\mathbf{0}$ & $\mathbf{0}$ & 2 & 2 \\
\hline $\begin{array}{l}\text { 11. Info in } \\
\text { numbers }\end{array}$ & $\mathbf{0}$ & $\mathbf{0}$ & 2 & $\mathbf{0}$ & $\mathbf{0}$ & $\mathbf{0}$ & $\mathbf{0}$ & $\mathbf{0}$ & $\mathbf{0}$ & $\mathbf{0}$ & 2 & $\mathbf{0}$ & $\mathbf{0}$ & $\mathbf{0}$ & $\mathbf{0}$ & $\mathbf{0}$ & $\mathbf{0}$ & $\mathbf{0}$ \\
\hline $\begin{array}{c}12 . \\
\text { Admissions }\end{array}$ & 2 & 2 & 2 & 2 & 2 & $\mathbf{0}$ & 2 & $\mathbf{0}$ & $\mathbf{0}$ & 2 & $\mathbf{0}$ & 2 & $\mathbf{0}$ & 2 & 2 & 2 & 2 & 2 \\
\hline $\begin{array}{c}\text { Total } \\
\text { Ratings } \\
(24 / 24)\end{array}$ & 21 & 19 & 17 & 19 & 19 & 11 & 14 & 14 & 17 & 18 & 15 & 20 & 12 & 18 & 10 & 11 & 21 & 19 \\
\hline
\end{tabular}

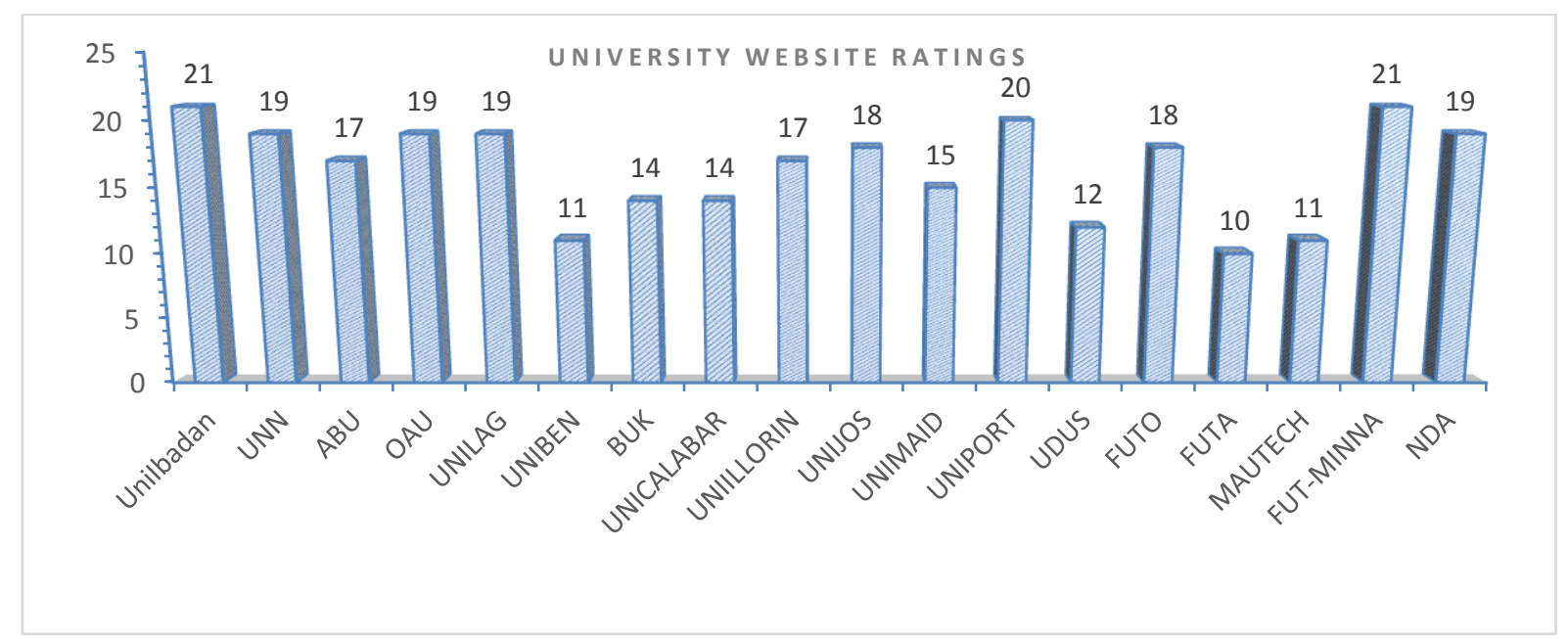

\section{Figure 1 Cumulative Evaluation and Ratings}

Generally, according to the analysis of the data in table $3 \&$ figure 1 above, 61.1\% of the websites are above average functioning with useful information represented in a proper pattern while $\mathbf{3 8 . 8 \%}$ are below average. In contrast to [22] all of the websites domain name has been improved according to the standard domain naming convention of .edu.ng. $\mathbf{6 1 \%}$ have (a) online catalogue or library that compose of useful resource materials and previous student graduation thesis while others are either empty, under maintenance or only display the opening days and hours of the library. It is worth mentioning that Uniport has the most impressive layout and detailed library materials that includes the Donald Ekong Library, Library repository, library catalogue, and a digital library with an in-house digital library browser. While $\mathbf{1 0 0} \%$ of the websites contains some degree of academic or educational (b) resources in form of Open Education Resource (OER), link to Online Open Journal sites, student time table, repositories, brochure, prospectus, student handbook and videos. (c) research interest and achievement are portrayed in many ways, $\mathbf{9 3 \%}$ showcase achievements as a slide in the home page of the websites or individual achievement in staff profile section. Thus, the same percentage lack proper listings of institutions specific research interest or field of specialization.
As opposed to earlier researches, all the websites are compatible with (d) mobile and portable devices except for few that have an un-organized layout in the mobile view. With the exception of $11.1 \%$ all the universities have (e) students portal, whilst (f) parents portal is not available in $78 \%$ of the websites with Unilbadan, Unilag, FUT-Minna exploring the best use of the feature, UniJos manage an available but non-functional link. $72 \%$ has good (g) content structing and layout putting into consideration good usability practices, some of the leading websites with good content structuring and layout consist of Uniport, Unilag, $\mathrm{ABU}$, UniIbadan, NDA, UNN while $22 \%$ has poor layout with many design discrepancies such as unedited "hello world" text or irrelevant text data, and 6\% has an average layout that need mild improvement.

However, $50 \%$ of the websites adopt a good usability and navigation practice of integrating a $(\mathrm{h})$ comprehensive search function in the main home page of the sites, and $11 \%$ manage an available but not functional search feature and not available in $39 \% .89 \%$ only list the name of courses offered in various departments without a (i) detailed course description while $11 \%$ list the courses with some slight details such as core subjects and credit unit of each module. 

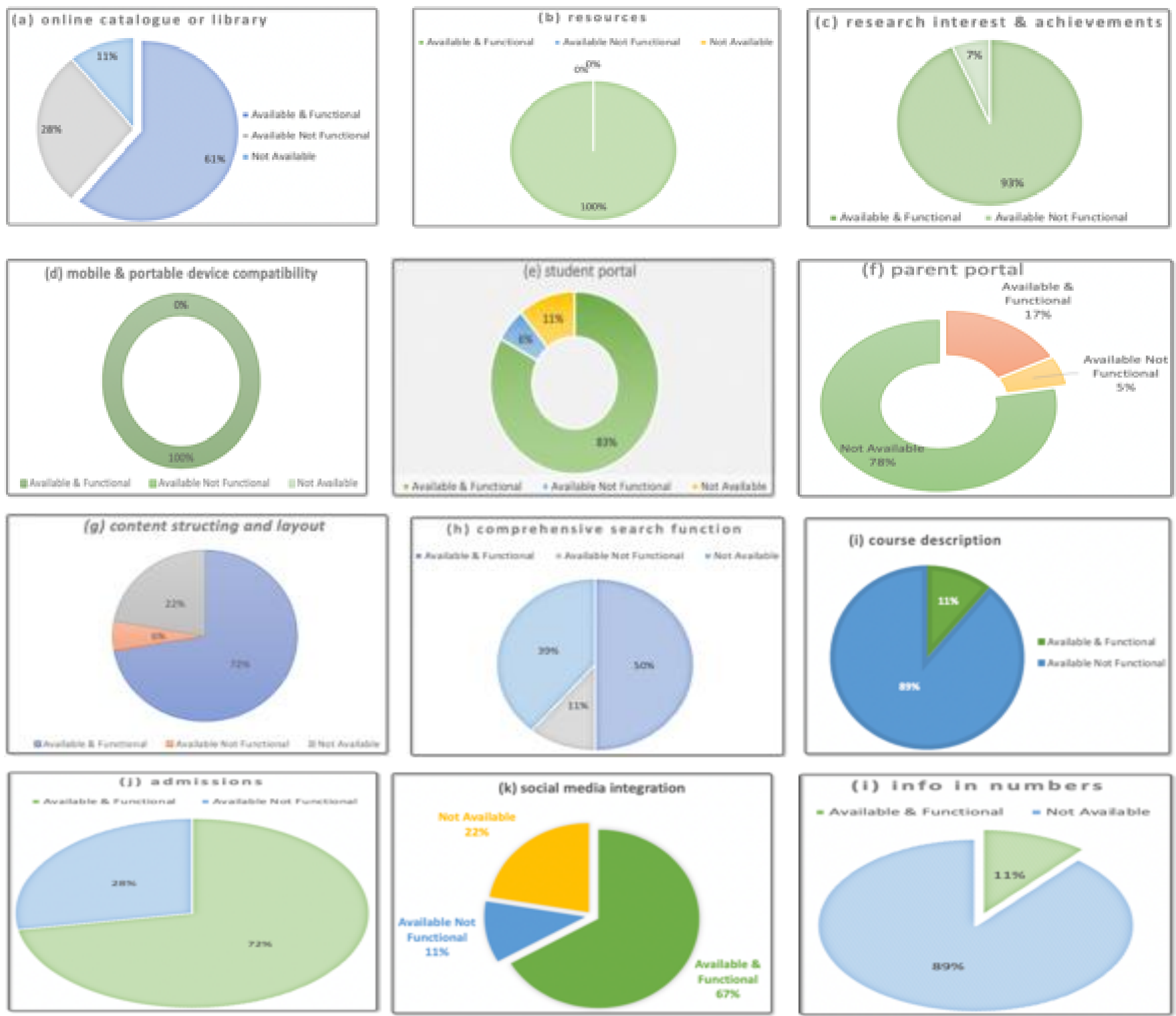

(j) admission is featured in $\mathbf{7 2 \%}$ of the websites in various format; others as PDF documents with name sorted alphabetically or portal to check admission status, or admission requirement info in the page, whereas the function is not available in the remaining $\mathbf{2 8 \%}$. Active $(\boldsymbol{k})$ social media handles are integrated in $67 \%$ of the sites, and $11 \%$ available not functional hyperlinks and $\mathbf{2 2 \%}$ not available. Notably, some of the universities have handles but are not integrated in the sites. $89 \%$ of the websites neglects the good approach of summarizing (l) Information in numbers except for $11 \%$ i.e. ABU \& UNIMAID.

\section{CONCLUSIONS}

As the need for information increases; the need for representing and conveying information in a proper and effective manner is exponentially increasing. Therefore, this study attempted to explore and shed more light on important university websites features that are lacking or difficult to assesses using automated tools and other evaluation techniques, using a novel benchmarking approach of analyzing unique features of world top ranking websites in comparison with available features of growing Nigerian university websites. the results were analyzed and discussed to show the overall strength, weakness and possible way of improvements of the websites involved in the study.

The results revealed that most of the universities succeeded in utilizing an online catalogue or library, mobile and portable device compatibility, student portal, resources, social media handles integration and admissions. However, improvement is required in terms of content, structuring and layout of the

Pages; as many discrepancies were noticed in this regard such as empty unedited templates, homepage with no organized information, outdated and irrelevant information, nonfunctional links or features among others. While others lack a functional search function that will help a user find direct information and information in numbers that will summarize the large textual content of the pages. Moreover, the outcome confirmed that a higher majority lacks detailed description of courses offered in the universities, which is considered to be one of the most important information needed by students and parent. The result also indicates the absence of parent portal in most of the websites.

The proposed functional framework criteria which are specific for the evaluation of educational or university websites can serve a number of purpose; provide guidance for designers, administrators, content managers and governing institutions 
such as NUC regarding website features that should be taken into consideration while designing and/or evaluating university websites.

\section{REFERENCES}

[1] A. A. Adebisi, A. N. Oluwatobi, and A. O. Adeola, 'Design and Implementation of a Mobile Students' Course Registration Platform Adigun', Int. J. Adv. Technol. Eng. Explor., vol. 2, no. 3, pp. 2394-7454, 2015.

[2] Z. Andalib and H. Danaee, 'A study on measuring the quality of university website', Grow. Sci. Ltd., vol. 3, pp. 1955-1960, 2013.

[3] A. A. Ojugo and A. O. Eboka, 'Assessing Users Satisfaction and Experience on Academic Websites: A Case of Selected Nigerian Universities Websites', I.J. Inf. Technol. Comput. Sci., vol. 10, no. October, pp. 53$61,2018$.

[4] S. M. Abdulhamid and I. Ismaila, 'DESIGN EVALUATION OF SOME NIGERIAN UNIVERSITY PORTALS ':, GESJ Comput. Sci. Telecommun., vol. 5, no. 5, pp. 21-28, 2010.

[5] S. C. A. Utulu and O. Bolarinwa, 'Contents and Architecture of Nigerian Universities ' Websites Addressing Web Contents Using Information Needs Theory', Issues Informing Sci. Inf. Technol., vol. 9, 2012.

[6] D. D. J. Suwawi, E. Darwiyanto, and M. Rochmani, 'Evaluation of academic website using ISO/IEC 9126', 3rd Int. Conf. Inf. Commun. Technol. ICoICT 2015, pp. 222-227, 2015.

[7] M. Astani and M. A. Elhindi, 'An empirical study of university websites', Issues Inf. Syst., vol. 9, no. 2, pp. 460-465, 2008.

[8] S. Qi, C. Ip, R. Leung, and R. Law, 'A new framework on website evaluation', Proc. Int. Conf. E-bus. EGovernment, ICEE 2010, pp. 78-81, 2010.

[9] J. Celic, A. Cuculic, and S. Valcic, 'Criteria for website assessment and evaluation', Pomor. Zb. 51, vol. 51, pp. 147-160, 2015.

[10] L. Hasan and E. Abuelrub, 'Assessing the quality of web sites', Appl. Comput. Informatics, vol. 9, no. 1, pp. 1129, 2011.

[11] W. M. Tsigereda, 'A framework for evaluating Academic Website's quality From students' perspective', Delft University of Technology Delft, The Netherlands, 2010.

[12] R. Anusha, 'A Study on Website Quality Models', Int. J. Sci. Res. Publ., vol. 4, no. 12, pp. 1-5, 2014.
[13] K. Devi and A. K. Sharma, 'Framework for Evaluation of Academic Website', Int. J. Comput. Tech., vol. 3, no. 2, pp. 234-239, 2016.

[14] F. Liu, 'Usability evaluation on websites', 9th Int. Conf Comput. Ind. Des. Concept. Des. Multicult. Creat. Des. CAIDCD 2008, pp. 141-144, 2008.

[15] A. Islam and K. Tsuji, 'Evaluation of Usage of University Websites in Bangladesh', DESIDOC J. Libr. Inf. Technol., vol. 31, no. 6, pp. 469-479, 2011.

[16] T. Alahmadi and S. Drew, 'Accessibility Evaluation of Top-Ranking University Websites in World, Oceania, and Arab Categories for Home, Admission, and Course Description Webpages', J. Open, Flex. Distance Learn., vol. 21, no. 1, pp. 7-24, 2006

[17] L. Hasan, 'Evaluating the Usability of Educational Websites Based on Students' Preferences of Design Characteristics', Int. Arab J. e-technology, vol. 3, no. 3, pp. 179-193, 2014.

[18] M. Chen and Y. Fu, 'Comprehensive evaluation of teaching websites based on intelligence methods', 2nd IEEE Int. Conf. Inf. Manag. Eng., vol. 4, pp. 177-181, 2010.

[19] P. D. D. Dominic and H. Jatim, 'Evaluation method of Malaysian university website: Quality website using hybrid Method', Proc. 2010 Int. Symp. Inf. Technol. Vis. Informatics, ITSim'10, vol. 1, 2010.

[20] S. C. A. Utulu, 'Webometric Ranking and Nigerian Private Universities : A Case Study of Bells University of Technology, Ota by', pp. 1-12, 1999.

[21] C. Kiyea and A. B. Yusuf, 'Usability Evaluation of Some Selected Nigerian Universities 'Websites', Int. J. Comput. Appl. (0975, vol. 104, no. 3, pp. 6-11, 2014.

[22] S. A. Olaleye, I. T. Sanusi, D. C. Ukpabi, and A. Okunoye, 'Evaluation of Nigeria Universities Websites Quality: A Comparative Analysis', Libr. Philos. Pract., vol. 1, no. 1, pp. 1-14, 2018.

[23] National Universities Commission, 'Federal Universities | National Universities Commision', Nigerian Universities, 2019. [Online]. Available: http://nuc.edu.ng/nigerian-univerisities/federaluniveristies/. [Accessed: 29-May-2019].

[24] Webometrics, 'World | Ranking Web of Universities: More than 28000 institutions ranked', 2019. [Online]. Available: http://www.webometrics.info/en/world [Accessed: 25-Apr-2019]

[25] M. Yalman and T. Kutluca, 'Future of E-Libraries in Universities', Procedia - Soc. Behav. Sci., vol. 47, pp. 2225-2228, 2012. 
8. Appendix A: TimeLine Achievement

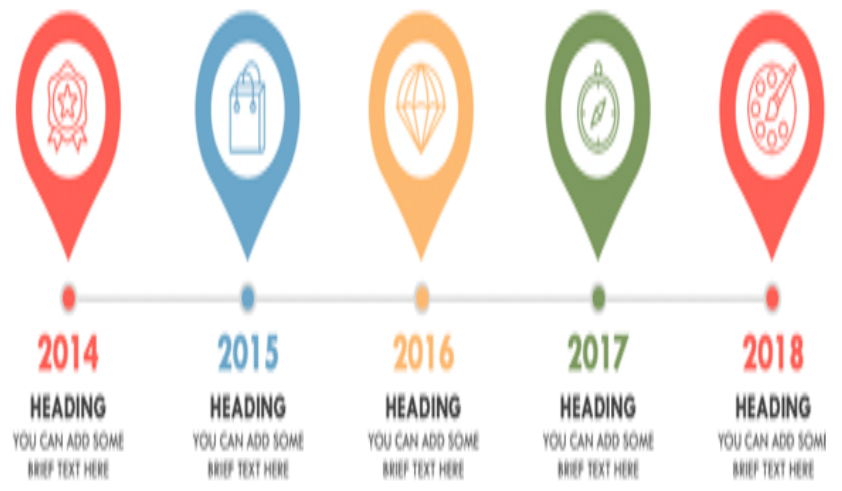

Figure 2 Timeline Achievement

\section{Appendix B: Detailed Course Description \\ Computer Science}

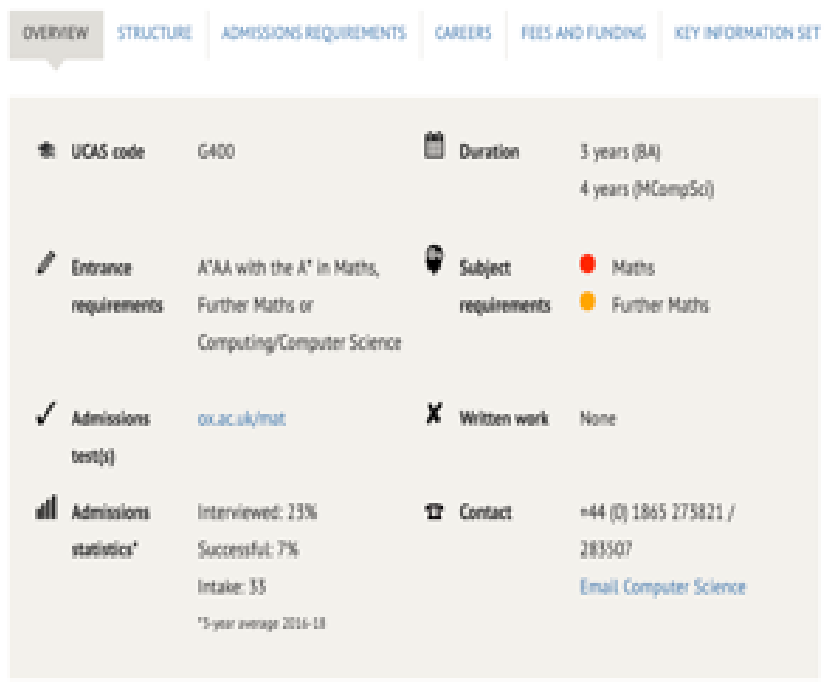

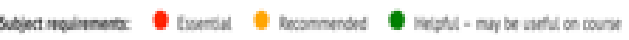

Figure 2 Course description e.g credit units, type, etc

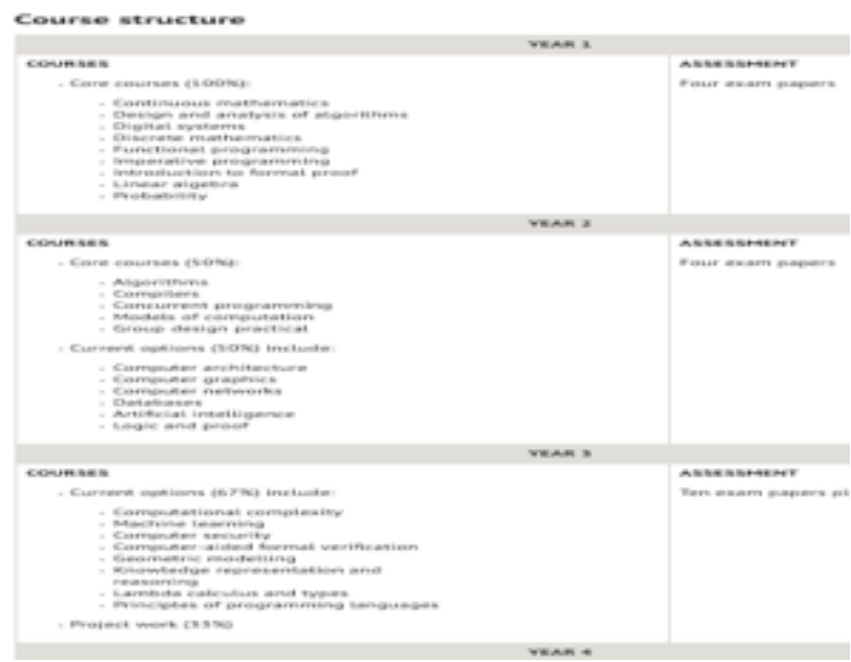

Figure 3 Courses offered according to semester

\section{Appendix C: Online Library}

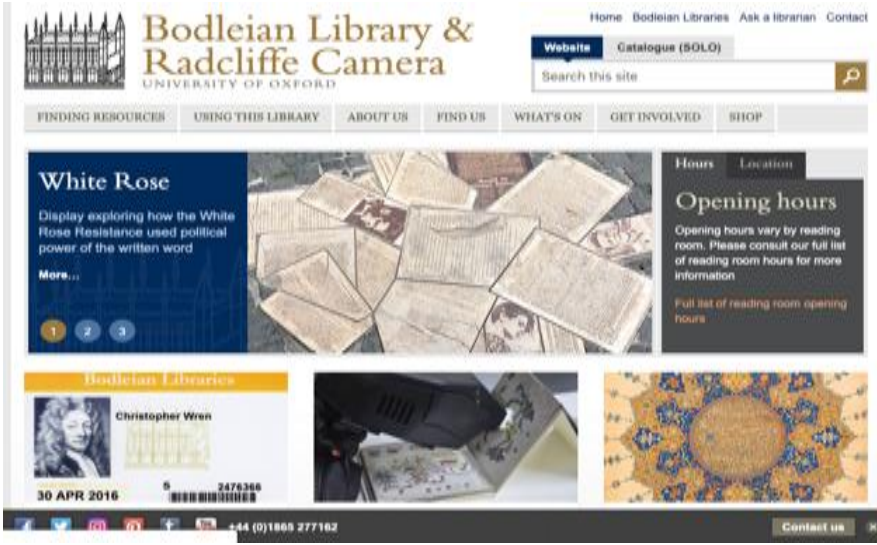

Figure 4 Library Sample Homepage

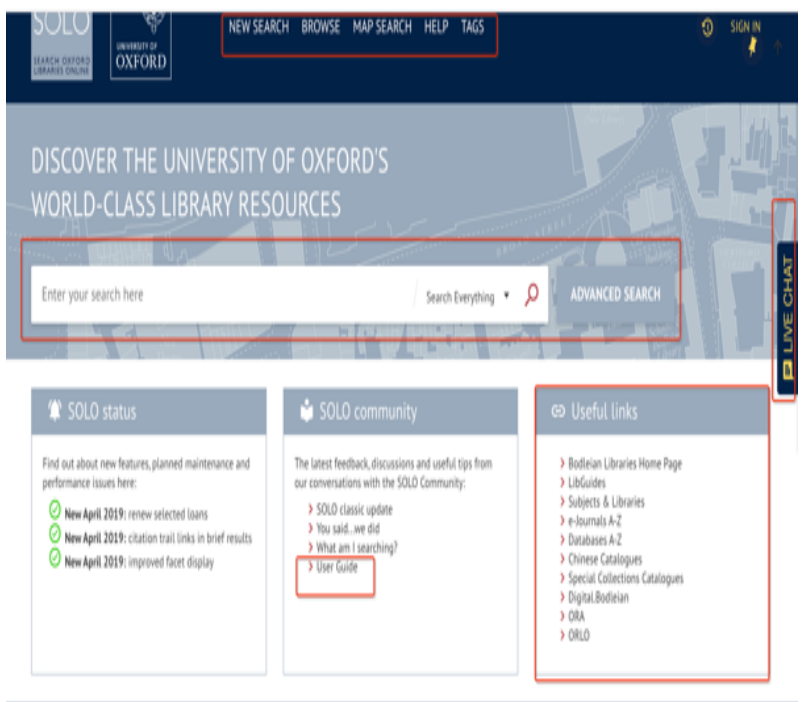

Figure 5 Comprehensive search function, user guide and useful links

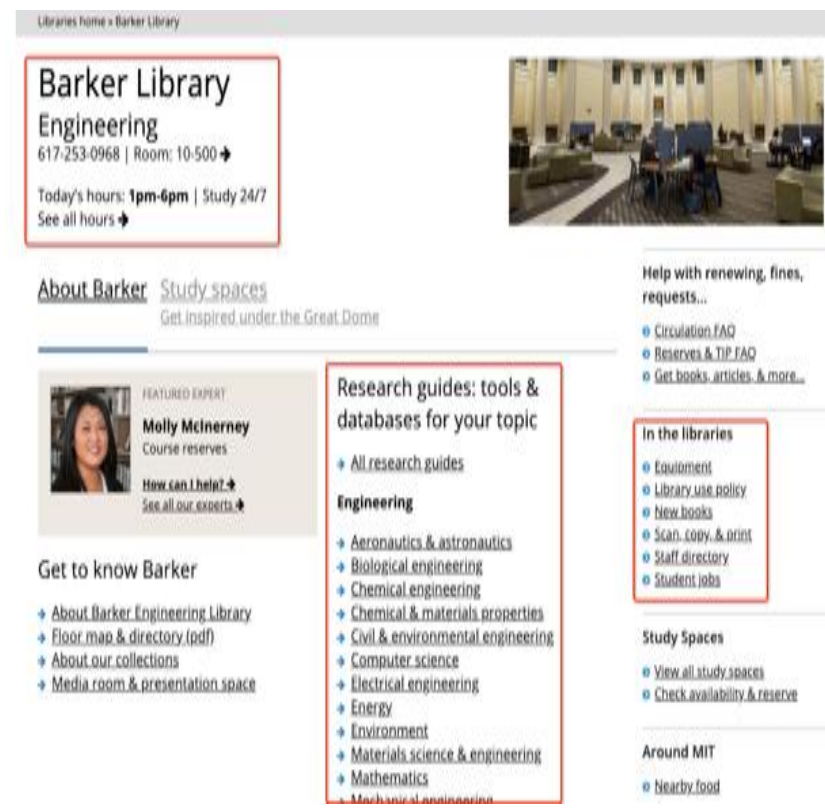

Figure 6 Library guideline $\&$ Policy plus research tools and other extended database tools 


\section{Appendix D: Parent Portal}

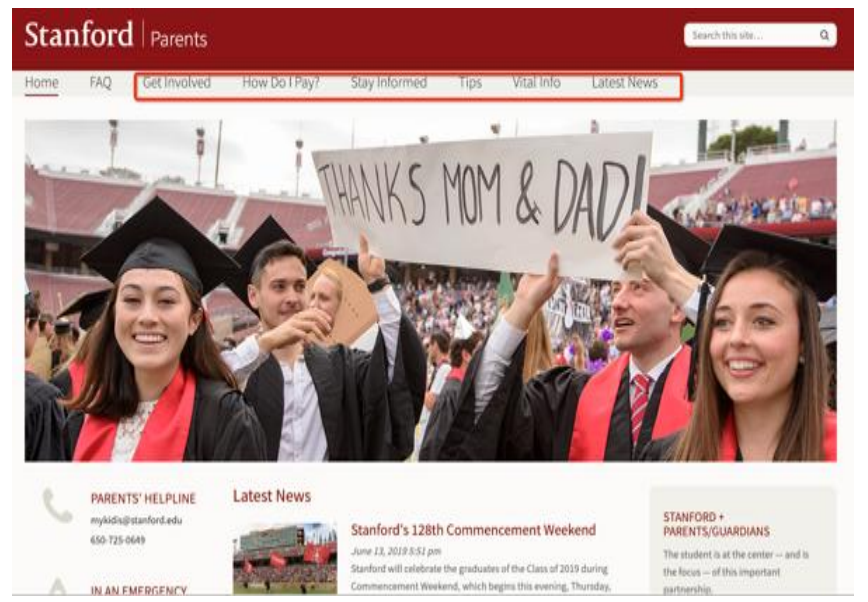

Figure 7 Parent portal

Appendix E: Info in Numbers

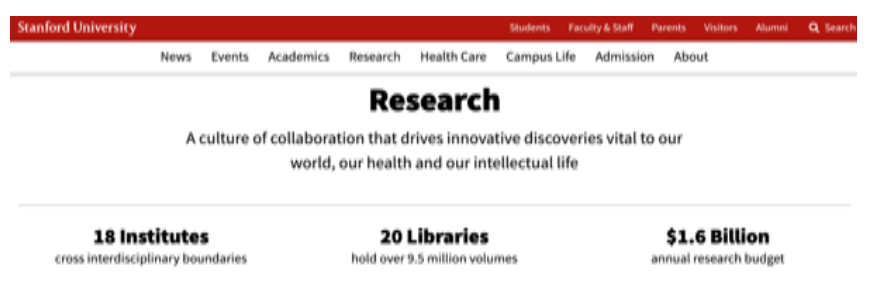

\section{About Stanford}

A place for learning, discovery, innovation, expression and discourse

Opened

$$
\begin{gathered}
\text { Students } \\
\mathbf{1 6 , 4 2 4}
\end{gathered}
$$

\section{Mare About stantori}

Figure 8 Sample Info in numbers as links e.g research \& About Stanford

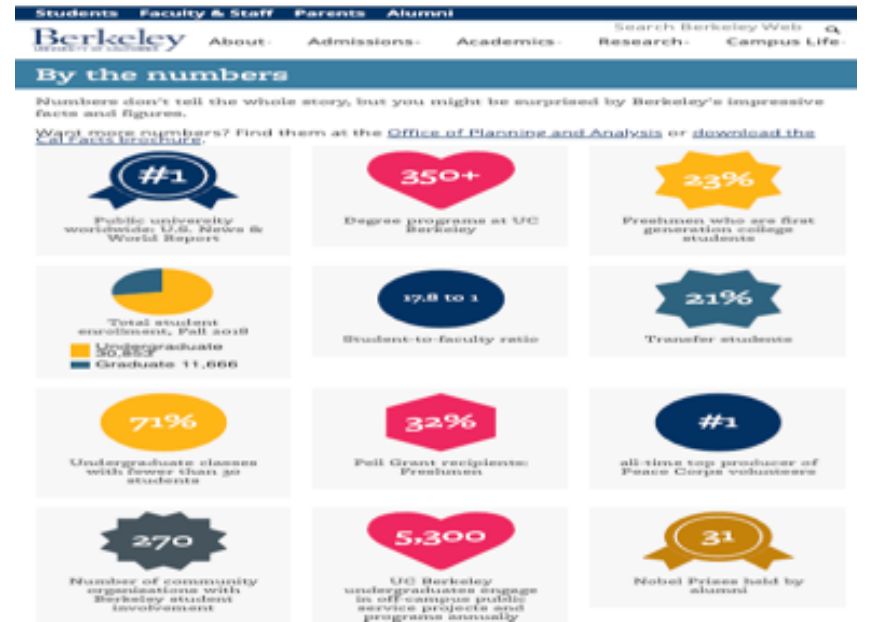

Figure 9 Info in Numbers Berkely University

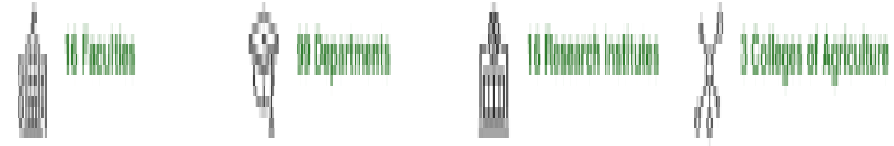

Figure 10 Info In Numbers of ABU

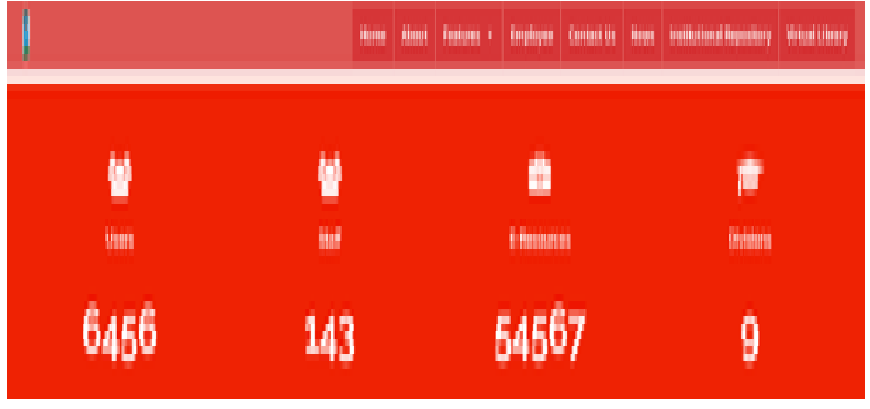

Figure 11 UNIMAID library Info in numbers

\section{Appendix F: Limitations of Other websites}
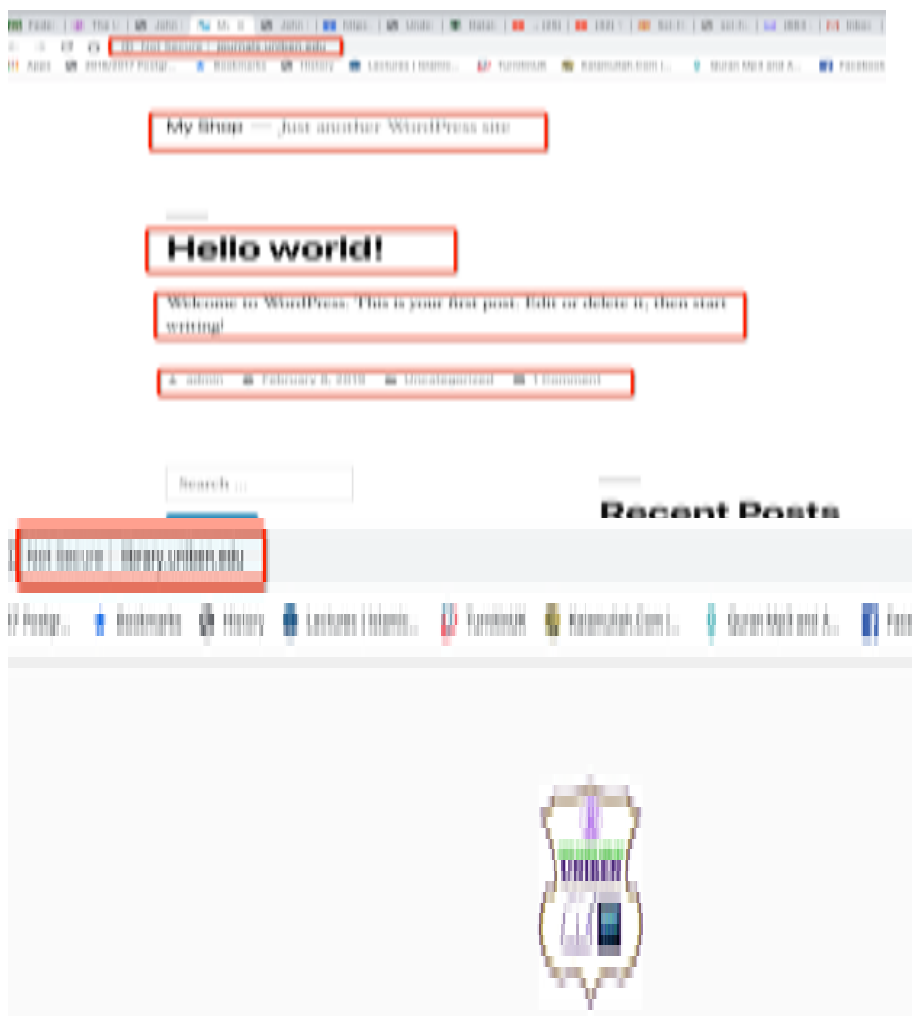

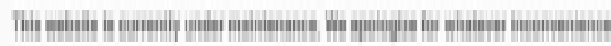

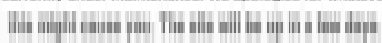

IIHin עint

Figure 12 UNIBEN Uncompleted pages 